2006

\title{
Publishers and Copyright: Rights Without Duties?
}

David Vaver

Osgoode Hall Law School of York University, DVaver@osgoode.yorku.ca

Follow this and additional works at: http://digitalcommons.osgoode.yorku.ca/all_papers

\section{Repository Citation}

Vaver, David, "Publishers and Copyright: Rights Without Duties?" (2006). All Papers. Paper 39.

http://digitalcommons.osgoode.yorku.ca/all_papers/39 


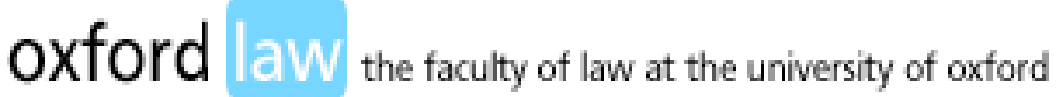

\section{Publishers and Copyright: Rights Without Duties?}

\author{
DAVID VAVER
}

\section{DRAFT}

Version of paper presented at the Sixth International Publishers Association copyright symposium, Montreal, April 23-25 2006, on Publishing \& The Public Interest, at the

Panel on the public image of publishers and copyright

\section{University of Oxford Faculty of Law Legal Studies Research Paper Series}

This paper can be downloaded without charge from the

Social Science Research Network electronic library at: http://papers.ssrn.com/Abstract $=902794$

An index to the working papers in the 
A version of this paper was presented at the Sixth International Publishers Association copyright symposium, Montreal, April 23-25 2006, on Publishing \& The Public Interest, at the Panel on the public image of publishers and copyright. DRAFT ONLY

\title{
Publishers and copyright: rights without duties?
}

\author{
David Vaver \\ Professor of intellectual property \& information technology law \\ University of Oxford
}

What does the public want of publishers? As book buyers, they want ready access to cheap and varied books in their language of choice. They don't want to be told a book is out of stock or in some language they can't read, and that they have to trudge round to some public library or antiquarian bookstore, or do their own surreptitious translation. As writers and users, they want fair access to the world's literature to have and to hold, to enjoy, to make fun of if they want, to build on it, and also to benefit and let others benefit from their endeavours. As authors, they want fair contract terms and a fair cut of the profits; for with no book, there is no profit.

Publishers are in business to make money and nobody begrudges them a decent living. People do begrudge them an indecent living: i.e., if they use their power to keep prices high, and make access and reuse of books difficult. Copyright law should be a means (1) to encourage authors to produce and benefit, (2) to encourage publishers to publish and keep publishing and profiting, and (3) to give the public cheap prices and easy access. It does (1) helping authors - modestly well; it does (2) - helping publishers - pretty well; whether or not it does (3) - giving the public what it wants - is more debatable. $1 \frac{1}{2}$ or 2 out of 3 is not good enough, especially since there's no point in helping authors and publishers if the public does not get what it needs and wants.

We need to rethink copyright law. Copyright should not just be about copyright owners' rights; it should also be about their duties. Historically, it used to be so: copyright owners used to owe duties to the public. Over time copyright law has been whittled down until it reads as if owners have just rights and no duties. They may have come to believe that; but the public hasn't.

Publishers have got copyright laws pretty well how they want them worldwide. The laws give them strong rights over the inventory they control: they can exploit their rights fully in both hard copy and digital form; they've even managed to lock up access to digital works through laws such as the DMCA in the US (the Digital Manacled Content Act). Sometimes they can even block imports that were lawfully produced abroad, and so can keep local 
prices high.

Publishers' control over media helps them shape the message about how benevolent their control is. Copyright stories get the right spin whenever they appear in newspapers and magazines. Copyright is presented as a wonderful invention without which no author would write, without which no newspaper or magazine would survive, without which we should all return to some neolithic age where communication occurs by grunts and chest-pounding (much like some current television shows). History is conveniently glossed over: people wrote and thought and painted and created for millennia before copyright laws came on the scene. Right up to the early $20^{\text {th }}$ century, newspapers in most places had no or very little copyright protection at all, and got on pretty well without it. In fact, a case could be made that the less copyright there was around, the more newspapers there were, and the greater variety of thought and opinion they provided.

Governments have bought into the "copyright is wonderful" picture, partly because they benefit from it too (and not just through taxes). Copyright protects their maps, stamps, their outsourced work, and (in some countries, including Canada) their laws and official documents. European directives on copyright blithely state that "a high level of protection" is needed to ensure "the maintenance and development of creativity in the interests of authors, cultural industries, consumers and society as a whole". "High level" in terms of time currently means until 70 years after the author has died, even though the copyright may be owned by the publisher, and the author's heirs receive nothing from it. That was one European idea that American publishers and their entertainment industry partners quickly imported, free of royalty of course.

The argument that consumers benefit by continuing to pay well above marginal cost for a product for a century or more after it was first marketed is either disingenuous or dishonest, especially where the same product would have been produced under a regime with a shorter period of protection or even no protection at all. Copyright here is just a cash cow to protect backlists. Authors may get something through trickle-down, but we know that only a handful manage to live off their writings alone.

As go America and Europe, so goes the world. Trade treaties make sure that the rest of the world shares this Amero-Eurocentric vision of copyright, whether they like it or not. If lesser developed countries want to export tea or bananas or textiles to Europe and North America, part of the price they must pay is to let European and American producers have copyright control over imported culture.

The push for high levels of protection leads logically to a situation where

1. Recital (10) of the EU copright term directive (1993); similarly, recital (9) of the EU information society copyright directive (2001), below, n. 8 . 
publishers get protected for ever. Walt Disney may be dead but the corporation he left behind makes no secret of its intention to ensure Mickey's worldwide legal immortality. This is one silly mouse that will produce mountains of law. ${ }^{2}$ Perpetual monopoly is of course every business person's dream; and publishers doze no differently. That we know from history.

From the late $16^{\text {th }}$ century London publishers ran a tightly knit cabal they called the Stationers' Company. They agreed to recognize one another's publication rights in perpetuity, and no books in the realm fell outside their grasp. The crown was complicit in their monopoly: the publishers helped the monarch censor, license and tax, and keep dangerous ideas from the rabble. The system eventually crumbled. By the $18^{\text {th }}$ century, others outside the publishers' circle didn't share its convenient vision and issued their own competing editions. The publishers went to court. True, legislatures by then had handed them up to 28 years copyright protection, but the publishers, like Oliver Twist, wanted more. They pressed the judges to ignore the legislatures and give them a perpetual copyright as well.

They lost in grand style. The supreme courts of England, Scotland and then (in the early $19^{\text {th }}$ century) the US rejected their claims. In England, Lord Camden called their case a "heterogenous heap of rubbish which is only calculated to confound your lordships and mislead the argument". In the florid rhetoric of the time, Camden dismissed the idea of a common law copyright in published works, in these words:

If there be anything in the world ... common to all mankind, science and learning are in their nature public domain, ${ }^{3}$ and they ought to be as free and general as air or water. They forget their Creator, as well as their fellow-creatures, who wish to monopolize his noblest gifts and greatest benefits. Why did we enter society at all but to enlighten one another's minds and improve our faculties for the common welfare of the species? ... The booksellers of late years have forestalled the market and become engrossers. If therefore the monopoly is sanctified by your lordships' judgment, exorbitant prices must be the consequence; for every valuable author will be as much monopolized by them as Shakespeare is at present... This perpetuity now contended for is as odious and as selfish as any other; it deserves reprobation and is become as intolerable. Knowledge and science are not things to be bound in such cobweb

2 "Parturient montes, nascetur ridiculus mus": Horace, Ars Poetica, 1. 139 ("the mountains labour and produce a silly mouse"). Sorry, Horace.

3 I have turned "publici juris" into "public domain". 


\section{chains... ${ }^{4}$}

The publishers lost in 1774 but their dreams didn't end there. Monopoly, once tasted, is addictive. The universities of Oxford and Cambridge and their colleges proved that. Startled by the 1774 decision, they got parliament next year to pass an act granting them (together with Eton, Westminster and Winchester) a perpetual copyright in all works bequeathed then and later to them. The UK copyright act of 1988 intervened to phase this monopoly out in 2039, just to replace it with another perpetual monopoly in J.M. Barrie's Peter Pan for the sick children's hospital in Great Ormond Street, London. ${ }^{5}$

Justice Oliver Wendell Holmes Jr famously said that "the life of the law has not been logic, it has been experience". Holmes was only half right: the life of the law has been neither logic nor experience, but lobbying. What publishers didn't get from judges they got from legislators. Legislators are easier pushovers.

Of course, very few people argue against the idea that copyright can be a useful tool to encourage authors to create and publishers to publish. The real point is what copyright law contains, and whether the monopoly it grants is now too long, too oppressive, too restrictive. ${ }^{6}$ It is, and publishers are as much to blame for that as any other industry group. Authors would write, publishers would publish, the public would read and use, everyone would still make plenty of money and most would be better off, with far less oppressive laws than those now on the statute books.

Let's look at three examples:

\section{(1) Copyright duration}

Inventors get 20 year patents for their new inventions. For centuries in Britain the term was even less: 14 years, the same initially as for copyright (although the author could renew for another 14 years if he wanted). 14 or 20 years: either way, that's thought to be long enough to encourage inventors to invent, bring their invention to market or encourage a venture capitalist to finance them, and recover sunk costs plus a decent profit. The same is true for

\footnotetext{
$4 \quad$ Donaldson $v$ Beckett (1774), HL.

5 Copyright, Designs \& Patents Act 1988 (UK), schedule 1 (s. 13(1)) (universities); s. 301 (hospital).
}

6 The word "monopoly" may grate but that's what it is, especially as publishing has become an oligopolistic industry increasingly concentrated in fewer corporate hands. 
publishers: European publishers of new editions of unpublished out-ofcopyright works and UK publishers of their own typeset editions get 25 years protection. Clearly no longer time is needed for works to turn a profit. Any publisher who actually worked to 20 or 25 year time scales to make money off a book wouldn't stay in business long. Authors wouldn't write less. They don't need a century or more of monopoly to encourage them. As Thomas Macaulay, a prolific writer himself, admitted in the $19^{\text {th }}$ century parliamentary debates on copyright term: "an advantage that is to be enjoyed more than half a century after we are dead, by somebody, we know not by whom, perhaps by somebody unborn, by somebody utterly unconnected with us, is really no motive at all to action". ${ }^{7}$

With shorter terms of protection, we wouldn't need 100 page or more reports from the US copyright office dealing with the "problem" of "orphan works" - material we want to reuse but can't because the copyright owner has disappeared. Orphan works are a $20^{\text {th }}$ century problem. There were no orphan works (although plenty of real orphans) through the mid $19^{\text {th }}$ century while copyright lasted 14 or 28 years, or even when the term doubled into the $20^{\text {th }}$ century. Orphan works are a problem because copyright now protects most written material for over a century. The older a work, the harder it is to trace its ownership. Shorten copyright duration, and suddenly every orphan work will find its parent.

Shorter copyright terms will certainly make works more accessible more quickly and bring prices down. Short term, it may harm some publishers; long term, it won't harm publishing. Just different publishers will get in the game. Authors and publishers will always find ways to add value to works and encourage the public to prefer one work over another. That's how food is sold: it's called marketing. Food for the brain is no different from food for the body.

\section{(2) Fair use and fair dealing}

Europe's law on fair use or fair dealing has always been more restrictive than that of the US. Whereas the fair use right in US law is open-ended, fair dealing in Europe is restricted to certain purposes only. The EU copyright directive passed in 2001 limits user rights still further. Before the directive, fair dealing for research purposes in the UK applied to both commercial and noncommercial uses, and criticism or review applied to both published and unpublished work. After the directive, only non-commercial research falls under fair dealing, and only published work can be quoted when criticized or reviewed. ${ }^{8}$

\footnotetext{
$7 \quad$ House of Commons, 5 February 1841.

8 Copyright, Designs and Patents Act 1988 (U.K.), ss. 29(1), 30(1) \& (1A), 39(1) \& (2)(a)(i), as am. in 2003, implementing art. 5(3)(a) \& (d) of the EU directive 2001/29/EC of $-5-$
} 
In concrete terms, what does that mean? In Canada, as a result of a decision of the supreme court, a courthouse library can photocopy legal judgments for lawyers, even if the lawyer is acting for profit. ${ }^{9}$ In the UK, neither the library nor the lawyer himself can do that now under the fair dealing or librarian's right: the lawyer's purpose is commercial and so neither right applies. The UK result is poor policy: legal research may not be the best example, but research generally promotes innovation, whoever does it or why. European patent holders cannot control research on their inventions, whether the work is academic, commercial, or a mixture of both. ${ }^{10}$ Nor should right holders control the direction of national research with copyright material.

In the US, an unauthorized biographer can copy reasonable extracts from his subject's unpublished letters to criticize or review his subject's life: that should be fair use. (J.D. Salinger did manage to stop Ian Hamilton from using large extracts from Salinger's publicly archived letters in the biography that Hamilton wrote; but US fair use provisions were changed and Hamilton's fair use claim seems more plausible today. ${ }^{11}$ ) In the UK, copyright law now forbids such quotes from unpublished material. Criticisms or reviews can use only "insubstantial" extracts. In 1972 the scientologists couldn't stop a chapter-andverse critique of their unpublished teachings from circulating; ${ }^{12}$ today they could. Why is a mystery. All a critic can now resort to is his constitutional right of free expression, with what results is anyone's guess. Maybe the publisher won't be subjected to an injunction but just damages: at least, that's how one court has suggested free speech rights can be reconciled with copyright. ${ }^{13}$ If that's so, free speech costs; and the way British courts award costs, it can cost dearly.

\section{(3) Authors on-line}

22 May 2001 on the harmonisation of certain aspects of copyright and related rights in the information society.

$9 \quad$ CCH Canadian Ltd. v. Law Society of Upper Canada [2004] 1 S.C.R. 339.

10 Community Patent Convention 1973, art. 27(b); Clinical Trials I \& II [1997] R.P.C. 623, [1998] R.P.C. 423 (BDH, Germany), aff'd [2001] GRUR 43 (Const. Ct.).

11 Salinger v. Random House Inc. 811 F.2d 90 (2d Cir. 1987); Copyright Act 1976 (US), s. 107, as amended: "The fact that a work is unpublished shall not itself bar a finding of fair use if such finding is made upon consideration of [the standard fair use] factors."

$12 \quad$ Hubbard v. Vosper [1972] 2 Q.B. 82 (C.A.).

13 Ashdown v. Telegraph Group Ltd [2002] Ch. 149 (C.A.); HRH the Prince of Wales v. Associated Newspapers Ltd. [2006] EWHC 522 (Ch.). 
As electronic distribution has come, authors have asked for their share of the action when publishers have put their work on-line or in electronic databases. Matters have not gone smoothly. Instead of accepting that authors should share in the profits of the new media, publishers have tried to keep everything to themselves. Litigation has followed worldwide: Tasini's case in the US favouring the author has its counterpart in Robertson's case currently before the Canadian supreme court. ${ }^{14}$

So here is the story: publishers go to legislatures and say the digital world has changed everything, and the law must be changed to tighten their control over electronic outputs. But authors coming to them are told that nothing has changed; it doesn't matter that they own the copyright. The article was paid for and putting it on the Web is no different from sticking it in the archives in the basement. Some archives; some basement.

I have said that copyright law today seems to be all about rights: the rights of owners. Everyone other than them, it seems, has responsibilities. Rights without responsibilities are wonderful things, especially for monopolists. We then forget the main reason these laws were passed from the outset: to quote from a WWI-vintage case from the US supreme court, "not the creation of private fortunes for the owners of [copyrights], but .. 'to promote the progress of science and the useful arts"'.

That thought applies equally to the rest of the world. Publishers are fond of talking of copyright's long history: the longer history an institution is shown to have, the more inevitable and natural the institution seems. But if history is not to be bunk, it should tell the whole story, not just part of it.

Copyright does have a long, although not ancient, history. The first statute is just under 3 centuries old, the English one of 1710. That statute, passed in the reign of Queen Anne, became the model for early American law. Some claim it was authors who pushed for the statute but that's only modestly true. Authors knew they would not get a penny more after the statute passed than they did before; and they were right. It was, again according to Camden, the stationers "who came up to parliament in the form of petitioners, with tears in their eyes, hopeless and forlorn; they brought with them their wives and

$14 \quad$ N.Y. Times Co. v. Tasini 533 U.S. 483 (2001); Robertson v. Thomson Corp. (2004) 243 D.L.R. (4th) 257 (Ont. C.A.), now before the SCC.

15 Motion Picture Patents Co. v. Universal Film Mfg. Co. 243 U.S. 502, 511 (1917), speaking of the court's approach to patents since the early $19^{\text {th }}$ century, but the same applies to copyright. 
children to excite compassion, and induce parliament to grant them a statutory security." 16

Interestingly, the statute was not called a copyright act: it was called "an act for the encouragement of learning". The legislature recognized that copyright was only a means to an end, and that with the rights it gave came duties. The preamble stated the statute's raison d'être: unauthorized printing was causing "very great detriment" to authors and book proprietors, "too often to the ruin of them and their families"; so the act was there "for preventing ... such practices for the future, and for the encouragement of learned men to compose and write useful books". Parliament provided an exclusive right for 14 years, renewable for another 14 years. The right was for authors but of course the publishers made sure it was transferable. Publishers acted as they always had done: authors had to sign over their whole interest as a condition of being published. Both the initial and the renewal terms typically became the publisher's for a once-and-for-all sum paid up front. ${ }^{17}$

Discussion of the statute usually stops there. But the act had other provisions. The copyright monopoly came along with duties imposed on publishers. ${ }^{18}$ As part of their obligation to encourage learning, they had to provide 9 free copies of the publication "upon the best paper" (no rubbish) to the centres of learning: the English and Scottish university libraries and Edinburgh's law library. Swingeing penalties were provided for failure: the value of the book, plus $£ 5$, plus costs, for each book not delivered.

Publishers also owed the public another duty: to keep prices "reasonable". ${ }^{19}$ If they didn't, anyone could complain to any of a number of worthies: the archbishop of Canterbury, the bishop of London, any chief judge, the vice-chancellor of the university of Oxford or Cambridge or his counterpart at Edinburgh. The tribunal could then summon the bookseller or printer to determine whether the price was right. If it wasn't, he could reduce it to what he thought was "just and reasonable." Again, a swingeing penalty was provided for disobedience.

It is interesting to speculate on how this law would look had it first been passed during our digital age. What duties would the legislature have imposed on publishers, as a condition of giving them nearly 3 decades' protection, to

16 Donaldson v. Beckett, above.

17 Carnan v. Bowles (1786) 2 Bro. C.C. 80. Royalty contracts became common only in the late $19^{\text {th }}$ century.

18 See generally Khong, "The Historical Law and Economics of the First Copyright Act" (2006) 2:1 Erasmus Law \& Economics Rev. 35.

Statute of Anne 1710, s. 4. 
make their work accessible to encourage learning? The idea of having book prices fixed by university presidents or vice-chancellors is surely an intriguing one.

Publishers owed legal duties of fair price and free access when the copyright term was only 28 years long, when their only exploitation right was to prevent outright copying of all or most of a work. They then had no power to stop translations, fair abridgments, even stage adaptations or performances. The copyright laws no longer impose the same legal obligations on publishers that they faced in the $18^{\text {th }}$ and $19^{\text {th }}$ centuries. But now that publishers have got copyright terms that run four or five times longer, now that they can control almost every way a work can be exploited, perhaps they should look into their souls and ask whether they do not continue to owe the public, morally at least, those same duties of fair price, fair access and fair contract. 